\title{
Attractiveness of protected areas for geotourism purposes from the perspective of visitors: the example of Babiogórski National Park (Poland)
}

https://doi.org/10.1515/geo-2018-0028

Received February 22, 2018; accepted June 13, 2018
Keywords: Babiogórski National Park, geotourism, tourist opinion, infrastructure

\section{Introduction}

It is not surprising that protected areas and tourism combines a long tradition of the mutual coexistence [1]. The region that protects the nature, also inanimate nature, is at the same time a set of tourist resources unique in its character. This can also serve as a base for the creation of the tourist product attractive both didactically and aesthetically. This value has been noticed long ago and in the last two decades it has significantly increased. For years the natural environment had its privileged position in the ecotourism or green tourism. It grows out of the sustainable development concept - a wider idea where nature is the main element to which all others like tourist infrastructure and accessibility is subordinated. The role of tourism in the natural heritage protection is emphasized by many authors [1-6] although at the same time the threats resulting from the human presence in the protected areas are stressed [7]. Two further issues are considered: resilience of the natural resources and knowledge combined with appropriate education. The interaction between these two

\footnotetext{
${ }^{\star}$ Corresponding Author: Krzysztof Widawski: Department of Regional Geography and Tourism, Institute of Geography and Regional Development, University of Wrocław, E-mail: krzysztof.widawski@uwr.edu.pl Zdzisław Jary: Department of Physical Geography, Institute of Geography and Regional Development, University of Wrocław Piotr Oleśniewicz: University School of Physical Education in Wrocław

Piotr Owczarek: Department of Physical Geography, Institute of Geography and Regional Development, University of Wrocław Julita Markiewicz-Patkowska: WSB University in Wrocław Anna Zaręba: Department of Regional Geography and Tourism, Institute of Geography and Regional Development, University of Wrocław
} 
factors reinforces the security of the natural resources [8]. It is important that the effects of ecological education, necessary to preserve nature in its unchanged form, were visible in many fields. It is not just the increased awareness of tourists and the local community, which is underlined by Bookbinder [9] or Valentine [10].

The specific activities related to the organization of tourist flow on the protected areas are also crucial. Ayoo [11] points out the importance of the appropriate attitude of the local community in using the resources of inanimate nature. If they develop the need to protect the natural resources and use them in a sustainable way they can use them for long [12]. It is often emphasized that success in tourism with the use of natural resources is also based on the appropriate level of services, high quality of the environment $[13,14]$ and the proper protection of its resources. The role of transport should also be pointed [15] together with the accommodation and other facilities for the persons visiting the protected areas [16]. Each element can affect the interest of tourists [17]. However, poorly planned infrastructure could stop the spread of tourism and, what is worse, it can destroy the natural resources thus the entire region may lose [18]. The sustainable approach in tourism in the protected areas is the subject of many studies conducted in the world $[19,20]$. Conducting such research would help to maintain better control over the tourist activity and its development and all parties using this in the region [21]. Cooperation with the local community is perceived as an indispensable element of preserving nature in the unchanged form [22, 23]. Guyer and Pollard [24] emphasize that tourism in the protected areas should be managed with the help of the local actors from the region, with particular emphasis on the local community including people living in marginal areas for whom the tourism is a real chance to change the fate.

The development of tourism in the protected areas along with an increase in the ecological awareness and the specialization of the tourist's preferences must have brought a new, dynamic and growing form of tourism geotourism. One of the very first definitions then developed has been proposed by Hose [4, 25-28] pointing that this form of tourism is "the provision of interpretive and service facilities enabling tourists to acquire knowledge and understanding of the geology and geomorphology of a site (including its contribution to the development of the Earth sciences) beyond the level of mere aesthetic appreciation". Newsome and Dowling [29] define geotourism as a kind of sustainable tourism, which focuses on the experience of the geological elements of the Earth on a way that helps to appreciate its environmental value together with appreciation of the need to protect on one hand and the economic need of the local community on the other hand. Geotourism is followed by its flagship product: geopark defined by UNESCO [30] "as a nationally protected area that contains a number of geological heritage sites of particular importance, rarity or aesthetic appeal, and is one element in an integrated concept of protection, education and sustainable development."

Protected areas like national parks (often achieving the status of a geopark) have been a special attraction for tourists for a long time. With the increase of mobility, education and leisure, their tourism usage has dramatically increased in the last two decades [31]. The majority of the protected areas deal on the one hand with conservation of the natural resources and on the other hand provide the opportunities for the development of recreation and tourism. To meet the need the national park managers are looking for information about the visitors and the type of experience they seek. It is important that (armed with this knowledge) they can maintain high quality of the resource - interesting and thus providing income for areas that need to be protected [7].

The postulate of the research on tourism needs in connection with tourism resources and regions is not new [7, 24, 32]. Such knowledge is helpful when creating a suitable product that takes into account the requirements of both parties: the tourists and the nature of the protected area $[33,34]$. It is worth asking the question of how the protected area is prepared for the reception of the tourist flow and how the tourist product is perceived by tourists using it. This article is based on the data collected from visitors to the Babiogórski National Park.

\section{Aims and methodology}

The hypothesis in this article boils down to the statement that protected areas with their proper development, are attractive for tourists visiting them. In order to check this the analysis of the tourist attractiveness elements like infrastructure or tourist resources has to be done. For this purpose stock-taking sightseeing method was used. The next step is to examine the opinions on the tourist attractiveness of geotourists visiting the Babiogórski National Park. For this article the analysis was made of those elements that refer directly to the Park (both resources and infrastructure), which affect the tourist attractiveness. The survey was conducted on 308 respondents in the tourist season of 2011. The research was carried out in four periods that are usually characterized by increased tourist traffic: 
1. The first long weekend (a long weekend is an accumulation of holidays associated with public holidays on working days and weekends): in 2011 it fell between April 28 and May 5. During that period the tourist traffic is usually increased but despite 9 free days only 66 surveys were collected. Such a low turnout was the result of adverse weather conditions - snow and rain, fog and a relatively strong wind made it difficult to visit, thanks to which few tourists, staying in the vicinity of the Park, decided to go on a mountain trip.

2. Mid-June (weekend 11 - 12 June) - the pre-holiday period; the majority of visitors are young people and school groups. Thanks to excellent weather conditions, 72 questionnaires were correctly completed.

3. Long weekend from 15 to 17 August. Thanks to good weather conditions and the accumulation of long-term tourist traffic and weekend trips, $30 \%$ of all surveys (94) were obtained.

4. The first half of September ( $5-7.09 .2011)$, mainly individual tourists, usually university students as it was still free-of-studies time for them.

Each time tourists or visitors were asked to judge both the quality of infrastructure as well as attractiveness of geotourist values together with their adaptation to reception by the tourist movement.

\section{Discussion and results}

\subsection{Babiogórski National Park - geomorphological approach}

Babiogórski National Park is located within the Western Beskids (Outer Western Carpathians) forming the westernmost part of the Carpathian arch. It covers the highest elevation of this part of the mountains with Babia Góra peak (1725 m. a.s.l.) Babia Góra is built from flysch of the Cretaceous and Paleogene ages [35]. The flysch creates a complex of conglomerates, sandstones, siltstones and claystones of variable thickness, which sedimentation took place from the Upper Cretaceous to the Early Miocene [36]. The folding and uplift of this formation occurred in the Neogene during alpine orogeny. Tectonic movements in this part of the Carpathians gave rise to large tectonic units - nappes, which were overthrust from the south to the north $[36,37]$. The largest and innermost unit of the Outer Carpathians is the Magura nappe. In addition to this unit, it can also be distinguished: Fore-MaguraDukla group, Silesian, Sub-Silesian, Skole and Boryslav-
Pokuttya nappes [35]. Rock complexes building the culmination of Babia Góra belong to the Magura nappe, which is mainly coarse sandstones. Babia Góra is a highly elevated range of about $10 \mathrm{~km}$, elevated almost $1000 \mathrm{~m}$ above the surrounding valleys. It has a clearly asymmetric shape. The northern slopes are precipitous, with numerous rock outcrops, slips and landslide landslides, while the southern slopes are gently sloping, referring to the fall of the Magura sandstones. In the relief of Babia Góra, a number of elements can be distinguished, which make it unique in the scale of entire Western Carpathians. Within the narrow ridge parts there are extensive rock debris formed during the cold periods of the Pleistocene. Within the ridge of the northern slopes at an altitude of $1350-1700 \mathrm{~m}$, there are different-shaped landslide forms modeled by rubble runoffs [38]. Glacial forms have been fragmentarily preserved being a result of local glaciation or the influence of the patches of long-lasting snow $[39,40]$. The depressions of landslide niches often fill the so-called waters "little pounds" (e.g. Wet Little Pound). These steep northern slopes pass into gentle slopes of the main ridge cut by numerous V-shaped valleys.

In terms of climate, the Western Carpathians belong to the Carpathian region of temperate, transitional climate [41]. Here, there is a spatial diversity of climatic relations characteristic for mountain areas mainly related to the height above the sea level [42]. The amount of precipitation depends on the height above sea level and location in the Carpathian chain. Babia Góra receives approx. $1475 \mathrm{~mm}$ [43]. In the course of the year the maximum rainfall falls on the summer half-year. The snow cover appears in mid-October and thaws from the end of March till the end of May [44, 43, 41]. At Babia Gora it is best in the Western Beskids to develop climatic floors which in height are convergent with plant levels. The original vegetation of the low-lying floor (about 550 - $1150 \mathrm{~m}$ above sea level) is Carpathian beech forest (Fagetum carpaticum) and in places spruce or fir-spruce forests [45]. The upper rack extends from 1150 to $1390 \mathrm{~m}$ above sea level. The dominant collection here is the Carpathian spruce forest (Piceetum excelse carpaticum). Above the forest border stretches the mountain pine (Pinetum mughi carpaticum) (1360 - $1650 \mathrm{~m}$ a.s.l.) and Alpine floor (1650 - $1725 \mathrm{~m}$ a.s.l.) [46]. Currently forest complexes especially the lower floors are replaced by artificial spruce cultures or through hay meadows, pastures and arable. 


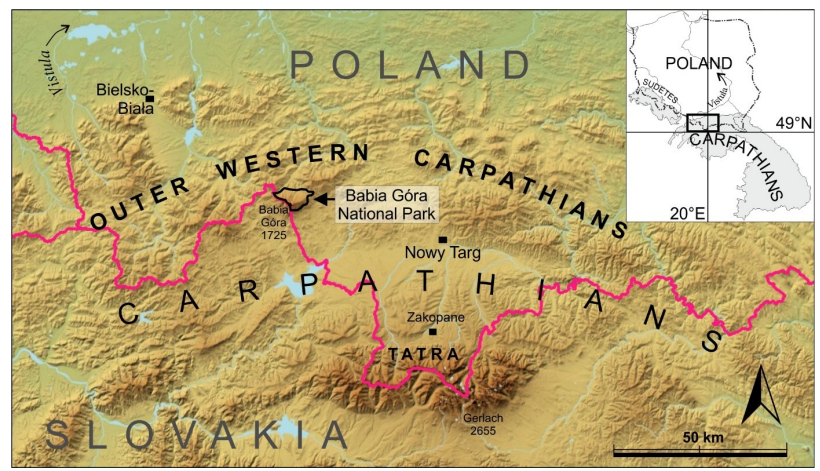

Figure 1: Location of the Babiogórski National Park within the Carpathian arch

\subsection{Babiogórski National Park as a protected area}

The necessity to protect the nature including its inanimate form has been noticed in Poland long time ago already. It is expressed in a multitude of forms of protection. Among the surface forms of the environmental protection one can enumerate: nature reserves, landscape parks, protected landscape area, nature 2000 area - implementing the policy of the protecting the areas in European Union, or finally - national parks, the most important form of the surface protection of the nature in the country. Its functioning is regulated by the highest (next to the constitution) legal act - National Protection Act - number 92, from 16 April 2004. National Park according to the above mentioned Act is defined as an area distinguished by its natural, scientific, social, cultural and educational values of the surface up to 1000 hectares where all the nature and landscape values are protected. The National Park is created "to preserve the biodiversity, resources, the components of inanimate nature and landscape values and to restore the proper state of the resources and components of nature...”. The crucial in the context of sustainable use of the protected area resources is the article number 12 introduced in 2012 which emphasizes the fact that "the area of the national park can be available in a way that will not adversely affect nature in the national park [47]".

The current state of protection clearly indicates the need for such management of the unique resources so that they can remain attractive also for the future generations. Although it is obvious now the awareness of the need to protect the inanimate nature in this area was present almost a century ago. The first postulates and specific actions appeared in the second decade of 20th century. As a result a reserve in the higher part of the massive in 1928 was created. Until 1933 the protected area covered 1045 hectares of land of the high-mountain, sub-alpine and
Table 1: Natural resources of Babiogórski National Park

\begin{tabular}{|l|l|}
\hline Kind of resource & Resource \\
\hline Water resources & Mokry Stawek, Głodna Woda \\
\hline Rocks & Borsucze Skały, Diablak, Piarżysty Żleb, Świstowe Rocks, Wołowe Rocks \\
\hline Viewpoints & Diablak, Wołowe Skałki, Kepa, Mała Babia Góra, Sokolica \\
\hline Others & Gruba Jodła, Babiogórski region plant's garden \\
\hline
\end{tabular}

alpine level. After the WWII the idea of enlargement of the protected area re-appeared. In 1954, October 30 the Babiogórski National Park was created (Dz. U. Nr 4, poz. 24 and 25). In 1997 park was enlarged again and now (together with the buffer zone) it occupies 11828.55 hectares. In the justification to the establishing of the National Park elements the following elements were considered among others: the significance of the relief (its relative altitude exceeds within the Park $1050 \mathrm{~m}$.) and is one of the highest in the Polish mountains, landslide pounds (unique in the Beskidy Mountain Range) and finally the endemic plants. It is worth mentioning the rank of the park - in 1977 Babiogórski National Park got the status of the UNESCO Biosphere Reserve as one of the first of its kind in Poland.

\subsection{Development of tourism and tourist resources of Babiogórski National Park}

Although located far from the most popular tourist routes like for example Tatra Mountain Range, Babia Góra massif was also a destination for the tourist trips starting from the 18th century. The result of the increasing popularity was the visit of Archduke Józef Habsburg in 1806 [48]. The first tourist routes appeared in the last decade of the 19th century. Ten years later a need for a permanent accommodation base appeared so two shelters were built [49]. An impetus in the development of tourism was the new communication accessibility in 1968 of the Lipnicka Pass which significantly shortened the time of entering the peak.

The Tourist attractiveness of the region mainly depends on the natural tourist resources. Among the most attractive ones it is mentioned: Mokry Pound or "Głodna Woda" sources, rocks and the rock complexes, viewpoints or the elements of the animate nature.

Among the inanimate nature resources the noteworthy are the rocks made of Masurian granite found in the highest parts of the massif. The largest cluster is located around the peak. Smaller fragments of rocks form vast rocky debris around the peak like in case of Piarżysty couloir, Treasure Hunters' Couloir or The Wide Couloir. 
The quite interesting offer that promotes the uniqueness of the regions' nature is the museum of Babiogórski National Park and the Babia Góra massif plants garden. The museum also functions as an educational center of the park.

\subsection{Tourist infrastructure of Babiogórski National Park}

Within the park there is only one accommodation unit - shelter in the clearing Markowe Szczawiany. After two years of renovation it was re-opened in 2009 and it offers 38 places in two, three, five and seven-bed rooms. Restrictions of the capacity of the accommodation units in the park are justified since according to the postulate presented in the Polish literature [50] within the national park there shouldn't be any facilities including accommodation, gastronomy nor communication bases outside the tourist routes, and only exceptionally (where it is justified with the real needs of tourism) individual shelters can be located inside the park.

Accommodation base which makes easy to explore the national park is concentrated in the neighbouring communities. In total the capacity of the three communities: Zawoja, Jabłonka and Lipnica Wielka reaches 3776 beds. Most of the places belong to houses (agritourism or guest rooms) and holiday resorts (together 1501 beds). It is worth emphasizing the upward trend of the development of a small-scale accommodation base among which the most important is agritourism. In 80 units 1109 tourists can be accommodated. Such trend is very important in the context of sustainable development of tourism: a scattered, small-scale accommodation base harms the natural environment in the least possible way.

The key to the proper functioning of tourism in the area of the National Park is the complementary base for tourist flow. Its role cannot be overestimated both in the correct implementation of the educational process (which is one of the important goals that are set for the park management) as well as in the correct channeling of tourist flow so as to minimize the changes in the park's biotopes.

It is worth paying attention to the fact that in the park area there are only the necessary elements of the tourist infrastructure including the tourist information points. All of them are located at the entrance to the park. They are available all season long from May to October. The same applies to the rain shelters and parking lots. The cohesion of the park infrastructure and the needs related to the protection of valuable natural resources is also indicated in the development strategy. Arcikiewicz [51] emphasizes
Table 2: Complementary base in Babiogórski National Park

\begin{tabular}{|l|l|}
\hline Elements of the complementary base & Quantity; ubication, \\
\hline Rain shelters & 11 \\
\hline Tourist information points & 3; Zawoja Markowa, Lipnicka Pass, Przywarówka \\
\hline Focal and educational circles & 3; Zawoja M., Policzne, Przywarówka \\
\hline Viewpoints & 2; Il serpentyna, Sokolica \\
\hline Parking & 3; Zawoja Markowa, Lipnicka Pass, Il serpentyna \\
\hline Seasonal wc in the summer & 3; Zawoja Markowa, Policzne, Lipnicka Pass \\
\hline Garbage containers in the summer & 3; Zawoja M., Policzne, Przełęcz Lipnicka \\
\hline
\end{tabular}

that Babiogórski National Park has sufficient infrastructure to handle tourist flow, hence no further expansion is planned but only modernization (taking into account the need to eliminate the negative impact on Babia Góra massif nature which is the priority).

The appropriately arranged tourist routes are important for the proper distribution of the tourists in the area of the park. The total length of these routes is almost $53 \mathrm{~km}$ which is $1.56 \mathrm{~km}$ of the routes per $1 \mathrm{~km}^{2}$ of the park surface. They are not evenly distributed and as the consequence the tourist flow is not distributed evenly as well. In total within the park there are 17 tourist routes of the length of $200 \mathrm{~km}$. The most common are hiking trails -12 . There are also three ski runs with the length from $1.5 \mathrm{~km}$ to $3 \mathrm{~km}$, one horse trail - from Ochlipów to Przywarówka of the length of $2 \mathrm{~km}$ and finally one bike trail - from Zawoja Policzone to Rajsztag $-8 \mathrm{~km}$ long. There are only three separated cross country ski routes of a total length of $6.8 \mathrm{~km}$. The horse trail enters the park boundaries only at the length of $2 \mathrm{~km}$ and most of it falls on the buffer zone. The same refers to the bike trail which was led around the outskirts of the park, along the provincial road 957, so it has a negligible impact on the Babia Gorra massif nature.

One of the most important tools for raising the environmental awareness and the respect for the valuable natural resources are the educational paths - commonly used in the educational tourism. This is one of the simpler and at the same time the most effective and attractive way of bringing closer the meaning of establishing and functioning of the protected areas. Babiogórski National Park offers eight different educational paths each of which has a separate theme.

The vast majority of educational paths are devoted to the nature conservation (also inanimate). This especially applies to Rybi Potokvalley where next to the presentations of the plants and animals of the area it is recommended to familiarize with the relief and the geological structure and the water phenomena of Babia Góra massif. 
Table 3: Educational paths in Babiogórski National Park

\begin{tabular}{|c|c|c|c|c|}
\hline Path's name & Route & Leading theme & $\begin{array}{l}\text { Number } \\
\text { of stops }\end{array}$ & $\begin{array}{l}\text { Length } \\
(\mathrm{km})\end{array}$ \\
\hline $\begin{array}{l}\text { In the footsteps of } \\
\text { Wawrzyniec Szkolnik }\end{array}$ & $\begin{array}{l}\text { Zawoja Czatorża - } \\
\text { Education center of } \\
\text { BNP }\end{array}$ & $\begin{array}{l}\text { Traditions of Babia Góra } \\
\text { highlanders, costumes, art, } \\
\text { traditional constructions }\end{array}$ & 5 & 2 \\
\hline $\begin{array}{l}\text { Echo of the primeval } \\
\text { Carpathian wilderness }\end{array}$ & $\begin{array}{l}\text { Loop starting from } \\
\text { Zawoja Czatorża }\end{array}$ & $\begin{array}{l}\text { Plant communities in the primeval } \\
\text { Carpathian forest }\end{array}$ & 10 & 2.4 \\
\hline $\begin{array}{l}\text { How we protect Babia Góra } \\
\text { nature }\end{array}$ & $\begin{array}{l}\text { Loop starting from } \\
\text { Zawoja Markowa }\end{array}$ & $\begin{array}{l}\text { Ways and forms of nature } \\
\text { conservation in BNP }\end{array}$ & 8 & 4.5 \\
\hline Rybi Potok valley & Ryzowana - Rybna & Fauna and flora of Babia Góra massif & 8 & 2.9 \\
\hline $\begin{array}{l}\text { In the lower mountain zone } \\
\text { of BNP }\end{array}$ & Rybna - Policzne & $\begin{array}{l}\text { Plant communities of the lower } \\
\text { mountain zone }\end{array}$ & 5 & 2 \\
\hline At the source of Black Sea & $\begin{array}{l}\text { Polana Krowiarki - } \\
\text { Zubrzyca Górna }\end{array}$ & $\begin{array}{l}\text { Hydrography of the area, } \\
\text { shepherding and forest } \\
\text { management, } \\
\text { constructions }\end{array}$ & 9 & 7 \\
\hline From Zawoja through & Zawoja - Lipnica & Altitudional zonation of & 19 & 25 \\
\hline Diablak to Lipnica & Wielka & vegetation of Babia Góra massif & & \\
\hline $\begin{array}{l}\text { Babia Góra with no } \\
\text { boundaries }\end{array}$ & $\begin{array}{l}\text { Markowe Szczawiny - } \\
\text { Slana Voda }\end{array}$ & $\begin{array}{l}\text { Nature and the shape of the slopes of } \\
\text { Babia Góra massif }\end{array}$ & 15 & 12 \\
\hline
\end{tabular}


The total length of these paths is $58 \mathrm{~km}$ and a significant number of the thematic stops allows tourists to get to know diverse elements of the local nature and culture practically every few hundred meters. It serves well both individual visitors and school groups which study during the field lessons the nature and its protection. At the same time it is worth emphasizing the course of these routes. Almost all of them were led along the edge of the National Park and its buffer zone. This is a deliberate procedure which is designed to relieve the center of the park from tourist traffic partly drained in this way on its outskirts contributing also to the protection of the park's most valuable natural areas.

\subsection{Natural resources and tourist services of Babiogórski National Park in the opinion of tourists}

The first decade of 21st century shows an upward trend in the volume of the tourist flow. Between 2000 and 2011 the number of tourists has increased from 50.000 up to 75.000 visitors.

It is worth taking a look at the opinions of the tourists using the tourist offer of Babiogórski National Park. The survey conducted during the season 2011 indicates a growing awareness of the need to protect the nature. Among 308 respondents the vast majority (96\%) were young people between 16 and 25 years old (32.5\%) or of working age up to 65 years old (63.6\%). More than half - $58.4 \%$ - were people of higher education usually more aware of the nature protection and sustainable development of the region than the rest of the community.

The main purpose of visit in Babiogórski National Park for the vast majority was a trip to the mountains that usually combines the need for active rest, aesthetic and cognitive experiences, which usually includes learning about nature both animate and inanimate of mountainous areas. Moreover, for the majority of people (87\%) Babia Góra massif was the biggest attraction and was a leading cause of the tourist migration. Slightly more than $10 \%$ indicated the peak as a secondary target while visiting the region. It is worth noting the seemingly unimportant question about the assessment of the price of the park entrance ticket. In the case of this question the price itself does not matter so much (although it is equivalent to 1.20 euro) but the approach to the idea of an admission fee for the legally protected area is interesting. The majority $-84 \%$ - of the respondents found it adequate since they accept the need for financial support of the park authorities' action aimed at nature conservation. This way they also support the de- velopment of the infrastructure accompanying the tourist flow which will finally lead to the optimization of the traffic reception with the protection mentioned above. This fact is very significant as the recognition of the need to co-finance by tourists of such park activities is an expression of increased awareness of the need to participate in the protection. Until the 90 s of the 20th century it was not so obvious and the proposal of admission fees met resistance.

It is worthy to know the opinion about the elements of the tourist infrastructure such as the trails which channels the tourist flow in a valuable natural area. These elements are extremely important for maintaining the ecosystem in an unchanged state.

Again the majority of the respondents - 95.1\% - highlights the fact that the trails are marked well or very well. This is important because trails are only possible ways to move around the protected area of the Park. Almost $90 \%$ of the respondents consider the proposed trails to be safe or rather safe. Just one person among 308 respondents thought the trails were definitely dangerous and four persons considered them rather dangerous (which makes $1.6 \%$ of the total number of respondents). There is no such unanimity as to the level of difficulty of the trails. For onefifth of respondents they are very difficult or rather difficult. This share probably refers to the so called "Akademicka perć" - a trail that overcomes relative altitude of $500 \mathrm{~m}$ over a distance of $2.5 \mathrm{~km}$. However already for almost half of the surveyed (45.8\%) the routes are not difficult, which probably has an impact on the increase in the attractiveness of the tourist offer of the area in the group of people who treat hiking in mountain areas rather amateurishly.

The density and length of the trails were assessed very positively. $82.5 \%$ of people questioned on the trial considered this to be sufficient in this shape and $3.6 \%$ was of the opposite opinion, which confirms the right decision taken by the managers of the National Park to optimize access to the most important natural resources. The cleanliness of the trails was rated high $-85 \%$ of respondents were satisfied with the state of the routes, while $8.5 \%$ were dissatisfied with the functioning of this element of the tourist infrastructure.

An important aspect of tourist attractiveness is the tourists' perception of natural values like rocks, water objects, views and panoramas or other elements encountered by them on the tourist trails. Of the total of 501 responses $60.3 \%$ found views and panoramas as the most attractive element which should not be surprising considering the mountainous landscape - one of the most attractive for tourist flow [52]. Every third answer pointed to rocks, especially rocks on Diablak peak and partly on "Akademicka Perć" trial. Less than 8\% indicated water element. Among 
other responses, vegetation was indicated, however this resource was significant for less than $2 \%$ of responders.

It is also worth mentioning which elements of the tourist infrastructure are missing on the tourist trails. The most indications (50\%) concerned the lack of garbage bins, which brings the problem of littering of the trails not an easy one to be solved. In national parks garbage bins are usually avoided because it causes a problem of their successive emptying. In addition, they should be adequately protected from wild animals living in the park. The education of tourists to be responsible for their own trash is necessary here.

Every third answer postulated an increase in the number of places for resting (33.1\%) especially in the central and dorsal zone of the park. Nevertheless, it would be difficult to fulfill because too much had to be interfered with the vegetation of the Alpine floor. However, it should be considered which would be more beneficial: the total absence of the recreation benches or wild campsites that possibly harm the vulnerable ecosystem. It is a postulate currently present in tourism and it refers to sustainable development, i.e. finding the right balance between nature and humans using natural resources.

\section{Conclusions}

Babiogórski National Park is one of the most valuable natural areas of Poland. It has valuable inanimate resources which are used for sightseeing or educational tourism. It is important to ensure proper tourist development of this protected area. All the activities should take into account the need for sustainable development. On the other hand resources should be made available in a limited way so that they would serve both the local community and the region's visitors during the next decades. Hence specific infrastructure in the park: a dispersed accommodation base with limited capacity located outside the protected area and even more dispersed in the buffer zone. Complementary infrastructure that facilitates tourist the penetration of the Park is primarily tourist trails, viewpoints and car parks. The managers of the Park emphasized the educational nature of the Park's resources by offering didactic paths that provide the most important geotouristic potential of the region. All these activities were fully appreciated by geotourists. They understand the need to protect and support the nature, appreciate geotouristic values and the way they are displayed. All this means that Babiogórski National Park can be considered an attractive geotourism area in the opinion of recipients of the offer and prospects for the development of geotourism in the Babia Gora massif in the context of sustainable development are promising.

\section{References}

[1] Bushell, R., Staiff, R., Eagles, P.F.J., 2007, 'Tourism and protected areas: Benefits beyond boundaries', in R. Bushell \& P.J.F. Eagles (eds.), Tourism and protected area: Benefits beyond boundaries, pp. 1-11, CAB International, Wallingford

[2] Dowling RK, Newsome D., 2006, Geotourism: sustainability, impacts and management. Elsevier, Oxford

[3] Honey M., 2008, Ecotourism and sustainable development: who own paradise? (2nd edn.). Island Press, Washington, DC

[4] Hose T. A., 1995, Selling the story of Britain's stone. Environmental Interpretation 10:16-17

[5] Panizza M., 2001, Geomorphosites: concepts, methods and example of geomorphological survey. Chinese Science Bulletin 46(Suppl.Bd.):4-6

[6] Słomka T, Kicińska-Świderska A (2004) Geoturystykapodstawowe pojęcia. Geoturystyka 1:5-7

[7] McCool, S.F., 2009, 'Constructing partnerships for protected area tourism planning in an era of change and messiness', Journal of Sustainable Tourism17(2), 133-148.

[8] Garavaglia V., G. Diolaiuti G., Smiraglia C.,Pasquale V., Pelfini M., 2012, Evaluating Tourist Perception of Environmental Changes as a Contribution to Managing Natural Resources in Glacierized Areas: A Case Study of the Forni Glacier (Stelvio National Park, Italian Alps), Environmental Management 2012, 50: $1125-1138$

[9] Bookbinder MP, Dinerstein E, Rijal A, and Cauley H. Ecotourism's support of biodiversity conservation. Conservation Biology 1998, 12:1399-1404.

[10] Valentine PS., 1992, Review: nature-based tourism. In: B. Weiler and C.M. Hall, editors. Special interest tourism, London: Belhaven Press; 1992, p.105-27

[11] Ayoo C., Community-based natural resource management in Kenya, Management of Environmental Quality: An International Journal 2007, 18:531-41.

[12] Tonge J., Moore S., Importance-satisfaction analysis for marinepark hinterlands: A Western Australian case study, Tourism Management, 28, 2007, 768 - 776

[13] Bushell, B. Global Issues for Protected Areas and Nature-based tourism: Case studies of partnership in Australia addressing some of these issues. In: L. Gunling, H. Korn, and R. Specht, editors. International workshop: Case studies on sustainable tourism and biological diversity. German Federal Agency for Nature Conservation, November 11-14, 1999. 2000, p.93-114.

[14] Eagles PFJ. International trends in park tourism: The emerging role of finance, The George Wright Forum 2003, 20:25-57.

[15] Buckley R. Pickering, C. and Weaver, DB. Nature-based tourism, environment and land management, Oxon: CABI Publishing.; 2003

[16] Priskin J. Assessment of natural resources for nature-based tourism: The case of the Central Coast Region of Western Australia. Tourism Management 2001, 22:637-48 
[17] Sandwith T., 2000, Nature-based tourism: a key strategy for sustaining biodiversity in KwaZulu-Natal, South Africa, [in:] L. Gunling, H. Korn, and R. Specht, editors. International Workshop: Case Studies on Sustainable Tourism and Biological Diversity, German Federal Agency for Nature Conservation, November 11-14; 1999, p.23-43

[18] Graterol BM. Preserving biodiversity through environmental impactassessment on tourism infrastructure: The case of wildlife. In: L. Gunling, H. Korn, and R. Specht, editor. International Workshop: Case Studies on Sustainable Tourism and Biological Diversity, German Federal Agency for Nature Conservation, November 11-14, 1999, 2000, p.60-80

[19] McIntosh, R.W., Goeldner, C.R., Ritchie, J.R.B., 1995. Tourism: Principles, Practices, Philosophies. John Wiley and Sons Inc, Wiley New York Chichester Brisbane Toronto Singapore.

[20] German Federal Agency for Nature Conservation (GFANC) (Ed.), 1997. Biodiversity and Tourism: Conflicts on the World's Seacoasts and Strategies for their Solution. Springer,Berlin, Heidelberg, Germany.

[21] Ceballos-Lascurain, H., 1996. Tourism Ecotourism and Protected Areas: the state of Nature-based Tourism Around the World and Guidelines for its Development. IUCN, Gland and Cambridge England

[22] Walpole, M.J., 2001, Feeding dragons in Komodo National Park: a tourism tool with conservation complications. Animal Conservation 4, 67-73

[23] Walpole, M.J., Goodwin, H.J., 2001, Local attitudes towards conservation and tourism around Komodo National Park, Indonesia. Environmental Conservation 28 (2), 160-166

[24] Guyer, C., Pollard, J., 1997. Cruise visitor impressions of the environment of the Shannon-Erne waterways system. Journal of Environmental Management 51, 199-215

[25] Hose, T. A., 1997, Geotourism - selling the Earth to Europe. Engineering Geology and the Environment. Rotterdam

[26] Hose, T. A., 2000, European Geotourism - Geological Interpretation and Geoconservation Promotion for Tourists. Geological Heritage: Its Conservation and Management. Madrid

[27] Hose T. A., 2005, Geo-tourism - appreciating the deep time of landscapes. Niche Tourism: contemporary issues, trends and cases. London

[28] Hose, T. A., 2011, The English Origins of Geotourism (as a Vehicle for Geoconservation) and their relevance to current studies. Acta Geographica Slovenica 51-2. Ljubljana

[29] Newsome D, Dowling RK, 2010, Geotourism: the tourism of geology and landscape. Goodfellow, Oxford

[30] UNESCO (2006) Global Geoparks Network. Accessed 7 April 2012 at: http://unesdoc.unesco.org/images/0015/001500/ 150007e.pdf

[31] Newsome, D., Moore, S. A., \& Dowling, R. K., 2002,Natural Area Tourism: Ecology, impacts and management. Clevedon, England: Channel View Publications.

[32] Panizza M, Piacente S., 2003, Geomorfologia culturale Pitagora Editrice, Bologna

[33] Bramwell, B., Lane B. 1993. Interpretation and sustainable tourism. Journal of Sustainable Tourism 1(2):71-80

[34] Burger, J. 1998. Attitudes about recreation, environmental problems, and estuarine health along the New Jersey shore, USA. Environmental Management 22(6):869-876
[35] Książkiewicz M., 1972, Karpaty [in:] W. Pożaryski (Ed.) Budowa Geologiczna Polski, T. 4. Wydawnictwo Geologiczne, Warszawa, pp. $3-228$.

[36] Oszczypko N., Oszczypko-Clowes M., 2012. Stages of development in the Polish Carpathian Foredeep basin. Central European Journal of Geosciences, 4 (1): 138-162

[37] Malata T., 2008, Development of Polish Flysch Carpathians revealed in outcrops and landscape. Przegląd Geologiczny, 56, 688-691.

[38] Aleksandrowicz, S., W., 1978, The northern slope of Babia Góra Mt. As a huge rock slump. Studia Geomorphologica CarpathoBalcanica, 12: 133-145.

[39] Łajczak A., 2005, Przyrodna nieożywiona, [in:] D. PtaszyckaJackowska (Ed.), Światy Babiej Góry, Babiogórski Park Narodowy, Zawoja, pp. 15 - 39.

[40] tajczak A., 2014, Relief development of the Babia Góra massif, Western Carpathian Mountains, Quaestiones Geographicae, 33, 1, Bogucki Wydawnictwo Naukowe, Poznań,

[41] Obrębska-Starklowa B., 2004, Klimat masywu Babiej Góry, [in:] B.W. Wołoszyn, A. Jaworski, J. Szwagrzyk (Ed.), Babiogórski Park Narodowy - monografia przyrodnicza, Komitet Ochrony Przyrody PAN, Babiogórski Park Narodowy, Kraków, pp. 137-151.

[42] Hess M., 1965: Piętra klimatyczne w Polskich Karpatach Zachodnich. Prace Geograficzne IG UJ., 1- 267.

[43] Paszyński J., Niedzwiedź T., 1999. Klimat. [in:] L. Starkel (Ed.) Geografia Polski - Środowisko Przyrodnicze. Warszawa PWN, 288 - 343. pp. 89-106.

[44] Obrębska-Starklowa B., Hess M., Olecki Z., Trepińska J., Kowanetz L., 1995: Klimat. [in:] J. Waroszyńska (Ed.) Karpaty Polskie. Wydawnictwo Uniwersytetu Jagiellońskiego, Kraków, pp. 31-47.

[45] Pawłowski B. 1977: Szata roślinna gór polskich. [in:] W. Szafer, K. Zarzycki (Ed.) Szata Roślinna Polski, T. 2. Warszawa PWN, pp. $189-252$.

[46] Holeksa J., Szwagrzyk J., 2005: Szata roślinna. [in:] D. Ptaszycka-Jackowska (Ed.), Światy Babiej Góry, Babiogórski Park Narodowy, Zawoja, pp. $43-93$.

[47] Ustawa o ochronie przyrody Dz.U. z 2009 r. Nr 151, poz. 1220, $\mathrm{Nr} 157$, poz. 1241 (https://www.nid.pl/upload/iblock/ 54c/54c7bc915f57027c5434c0622ee4c09b.pdf)

[48] Płaza J., 2004b, Turystyka w Babiogórskim Parku Narodowym, [in:] Wołoszyn B.W., Jaworski A., Szwagrzyk J., (Ed.) Babiogórski Park Narodowy. Monografia przyrodnicza, Komitet Ochrony Przyrody PAN, Babiogórski Park Narodowy, Kraków

[49] Płaza J., 2004a, Turystyka w Babiogórskim Parku Narodowym, [in:] Rocznik Babiogórski 2004, vol. 6, Stowarzyszenie Gmin Babiogórskich, Babiogórski Park Narodowy, Kraków-Zawoja

[50] Ptaszycka-Jackowska D., Baranowska-Janota M., 1989, Zasady korzystania z przyrodniczych obszarów chronionych, Wydawnictwa Geologiczne, Warszawa

[51] Arcikiewicz A., 2009, Turystyka w Babiogórskim Parku Narodowym, [in:] Rocznik Babiogórski 2009, vol. 11, Stowarzyszenie Gmin Babiogórskich, Kraków-Zawoja

[52] Wyrzykowski, Lijewski, Mikułowski, 2008, Geografia turystyczna Polski, PWE, V-th edition, Warszawa 